\title{
Ambrosia Beetles, Platypus spp. (Insecta: Coleoptera: Platypodidae) $)^{1}$
}

T. H. Atkinson ${ }^{2}$

\section{Introduction}

The family Platypodidae includes approximately 1,000 species, most of which are found in the tropics (Schedl 1972). Seven species of platypodids, all in the genus Platypus, are found in the United States, four of which occur in Florida. All species found in Florida are borers of trunks and large branches of recently killed trees and may cause economic damage to unmilled logs or standing dead timber. The most recent key to species was published 60 years ago (Chamberlin 1939), does not include all species known from the United States (Wood 1979), and has long been out of print.

\section{Identification}

The Platypodidae are closely related to the Scolytidae, but can be distinguished by the elongate body form, short abdomen (shorter than metathorax in lateral view), and elongate first tarsal segment which is longer than the remaining segments combined.

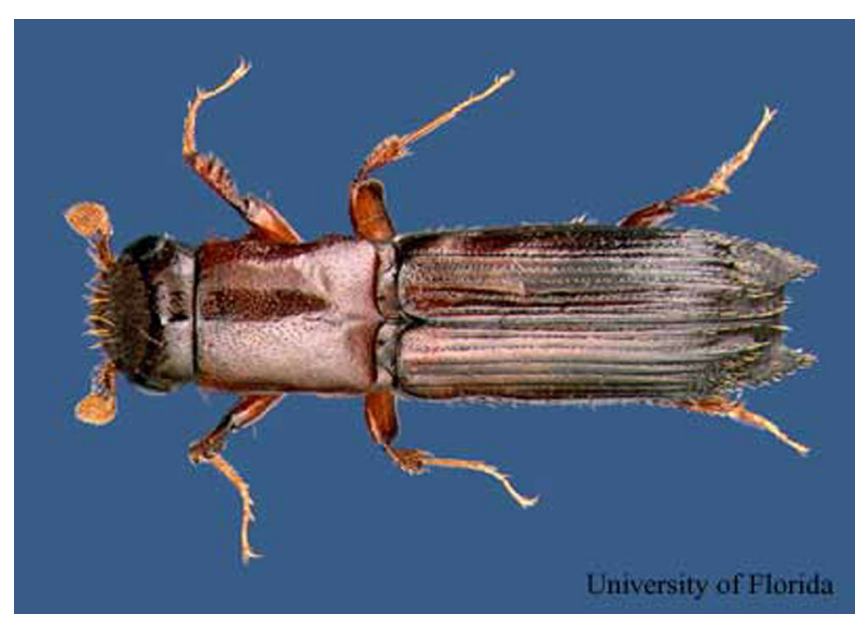

Figure 1. Dorsal view of male Platypus flavicornis Fabricius. Credits: David T. Almquist, University of Florida

Males of all species have more developed armature [spineous or chitinous processes] of the elytral declivity [sloping area] than females.

Females of species occurring in Florida lack terminal spines on the elytra except for Platypus flavicornis (Fabricius) which has blunt projections. Females of all species have larger maxillary palpi and a larger gular region than males. [See figures displaying ventral view of heads.]

1. This document is EENY-174 (originally published as DPI Entomology Circular 321), one of the Featured Creatures series of the Entomology and Nematology Department, Cooperative Extension Service, Institute of Food and Agricultural Sciences, University of Florida. Published: November 2000. Revised: March 2004. This document is also available on Featured Creatures Website at http://creatures.ifas.ufl.edu. Please visit the EDIS Website at http://edis.ifas.ufl.edu. Additional information on these organisms, including many color photographs, is available at the Entomology and Nematology Department website at http://entnemdept.ifas.ufl.edu/.

2. T. H. Atkinson, Entomology and Nematology Department, University of Florida, Gainesville, FL.

The Institute of Food and Agricultural Sciences (IFAS) is an Equal Employment Opportunity - Affirmative Action Employer authorized to provide research, educational information and other services only to individuals and institutions that function without regard to race, creed, color, religion, age, disability, sex, sexual orientation, marital status, national origin, political opinions or affiliations. For information on obtaining other extension publications, contact your county Cooperative Extension Service office. Florida Cooperative Extension Service / Institute of Food and Agricultural Sciences / University of Florida / Larry R. Arrington, Interim Dean 


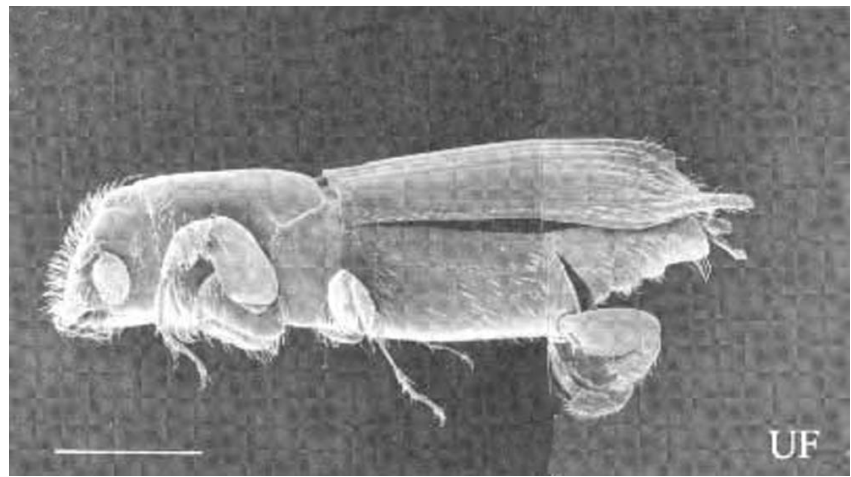

Figure 2. Lateral view of adult male Platypus flavicornis (Fabricius). White line represents $1 \mathrm{~mm}$. Credits: T.H. Atkinson, University of Florida

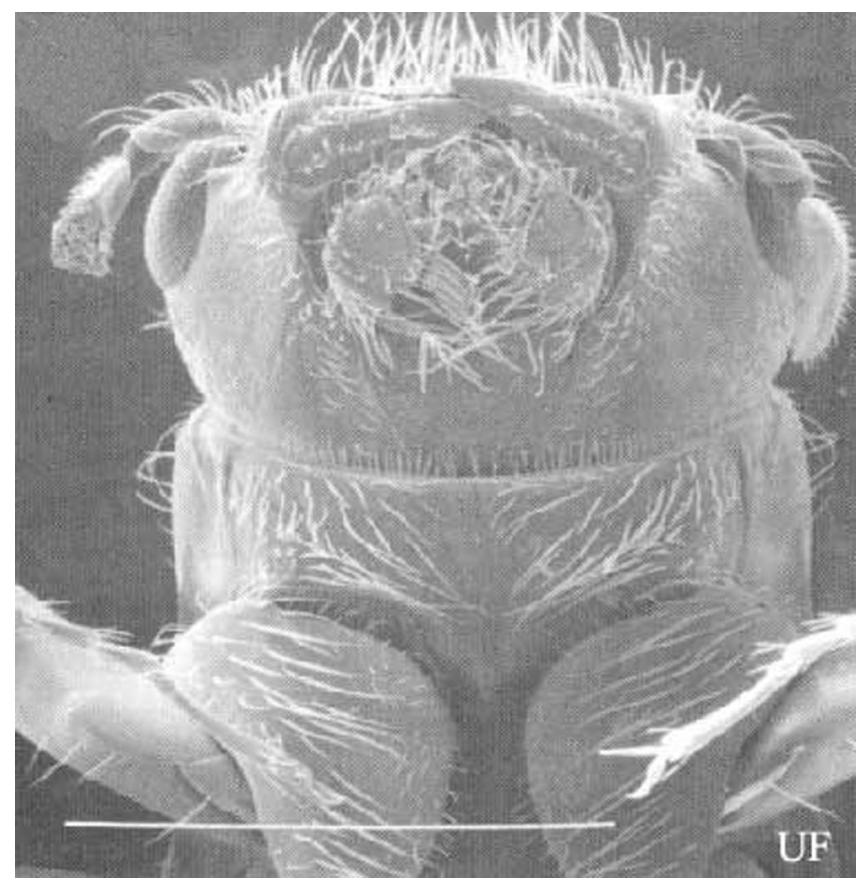

Figure 3. Ventral view of head of an adult female Platypus flavicornis (Fabricius). White line represents $1 \mathrm{~mm}$. Credits: T.H. Atkinson, University of Florida

The following key and accompanying illustrations will allow identification of both sexes of all species occurring in Florida and the eastern United States.

\section{Key to Species of Platypus of Florida}

1. Male declivity with large acuminate process arising from interstria 9 on posterolateral margins of elytra; interstria 3 continuing posteriorly as a spinose process, interstria 1 not elevated (Figures 8, 14); female declivity with blunt projection at apex of interstria 3 or at apex of interstria 9, apical margin of

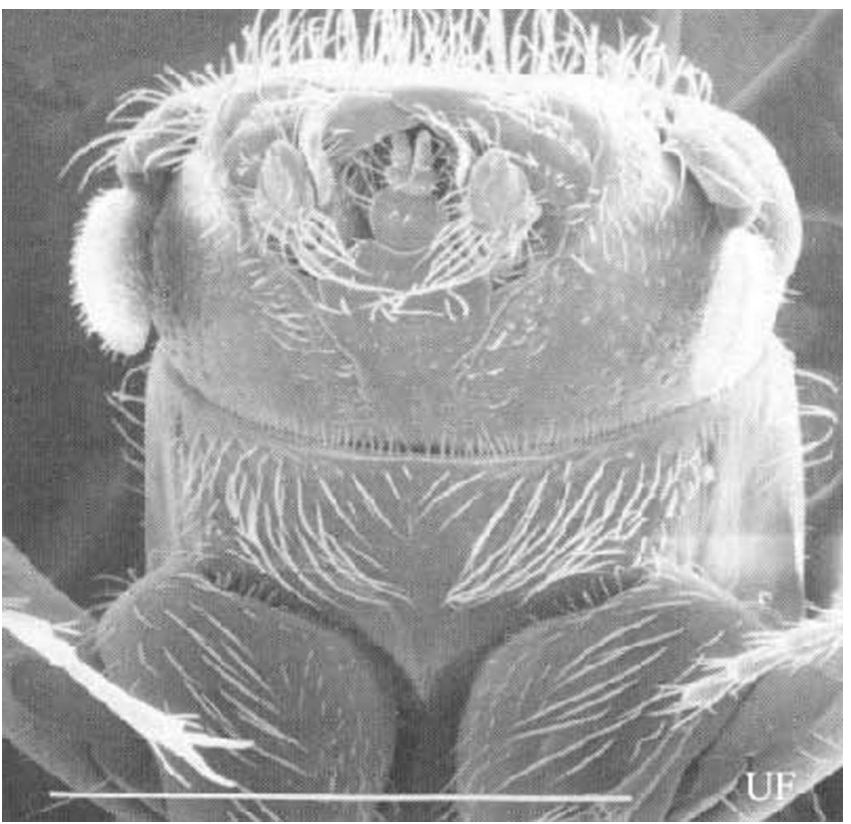

Figure 4. Ventral view of head of an adult male Platypus flavicornis (Fabricius). White line represents $1 \mathrm{~mm}$. Credits: T.H. Atkinson, University of Florida

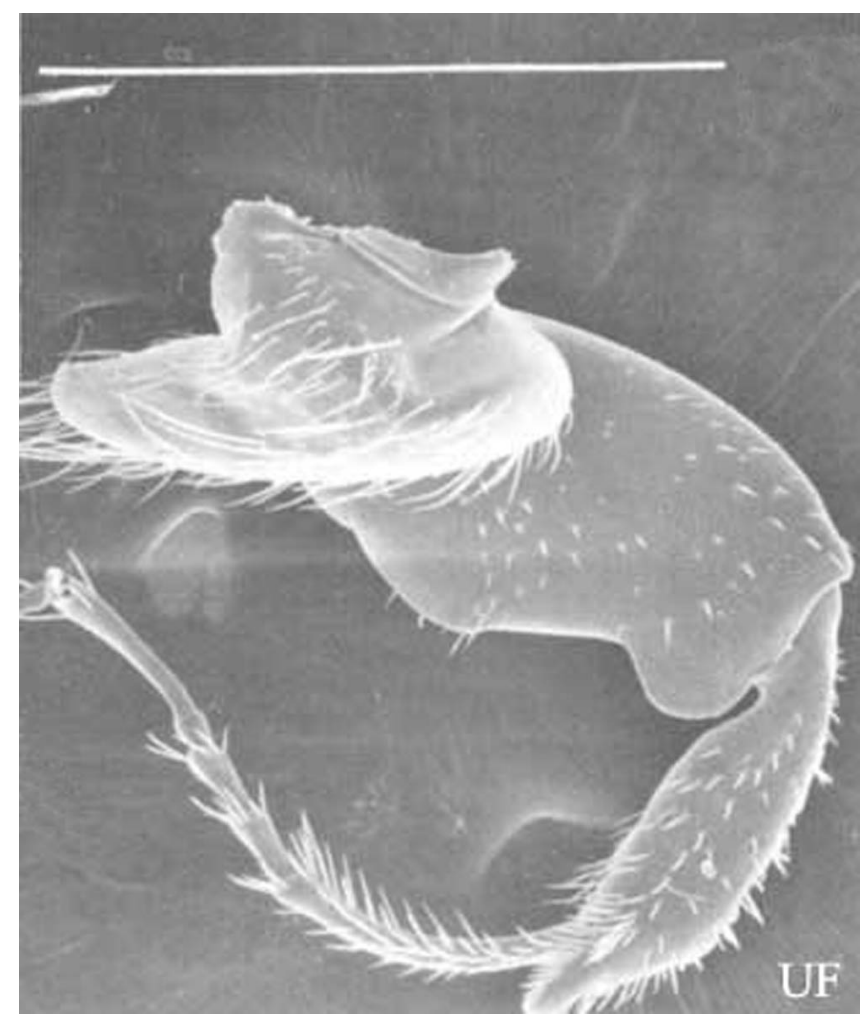

Figure 5. Prothoracic leg of Platypus flavicornis (Fabricius) showing length of tarsal segments. White line represents 1 $\mathrm{mm}$. Credits: T.H. Atkinson, University of Florida

declivity straight, not explanate (spread out and flattened) (Figures 9, 15) . . . . 2 


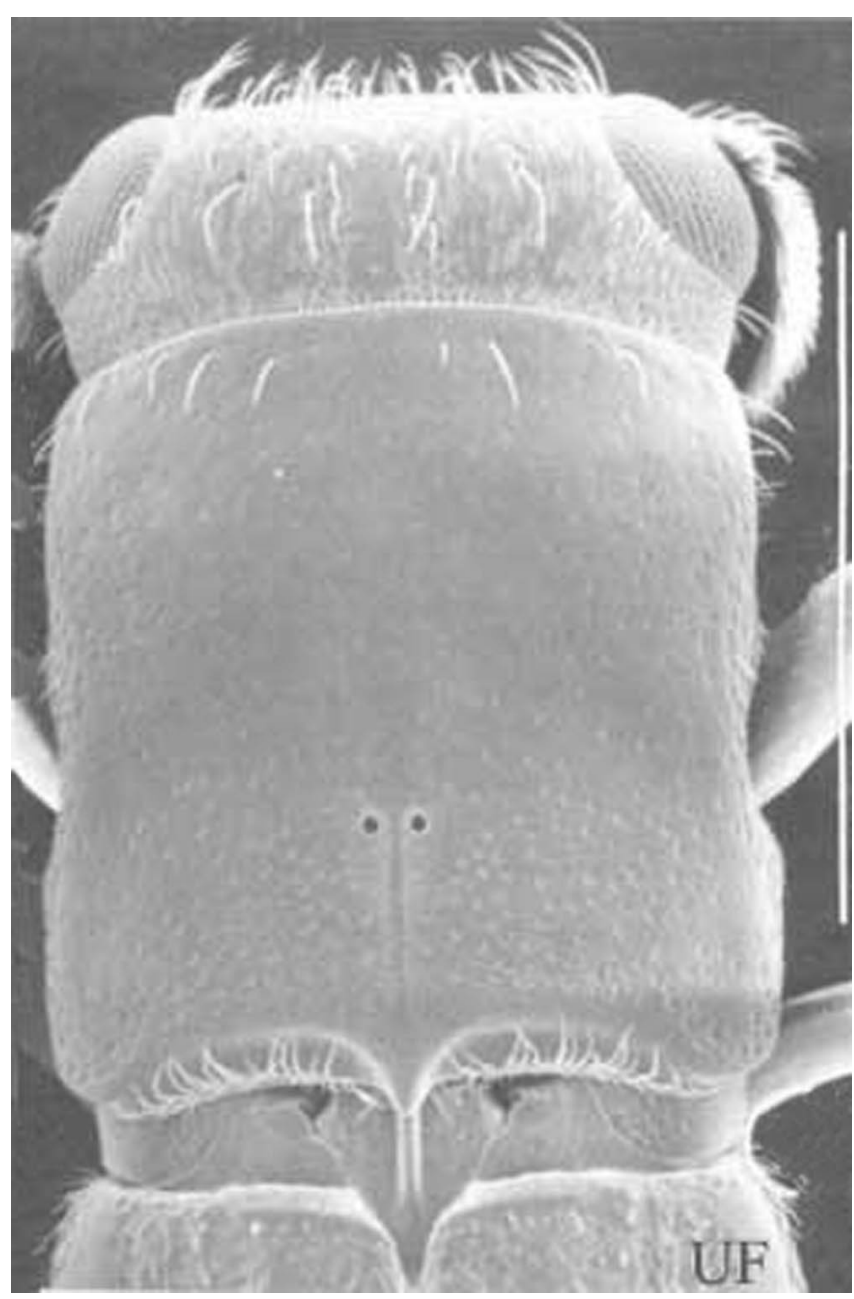

Figure 6. Pronotum of adult female Platypus compositus (Say). White line represents $1 \mathrm{~mm}$. Credits: T.H. Atkinson, University of Florida

1' Male declivity with large blunt process arising from interstria 9 on posterolateral margins of elytra ending in three terminal spines; interstria 1 continuing posteriorly as a spinose process, interstria 3 not elevated or conspicuously less so than 1 (Figures 10, 12); female declivity blunt, without projecting apical tubercles or processes, apical margin of declivity shallowly divaricate (forked) at suture, slightly explanate (Figures 11,13$) \ldots .3$

2(1). Male declivity with prominent spines on venter of third visible abdominal segment, posterolateral processes of declivity laterally compressed (Figure 14); female declivity without apical projection of posterolatreal area of elytra (Figure 15); female pronotum with pair of large conspicuous pores in middle (Figure 7). Southeastern U.S. In oaks ... . quadridentatus (Olivier)

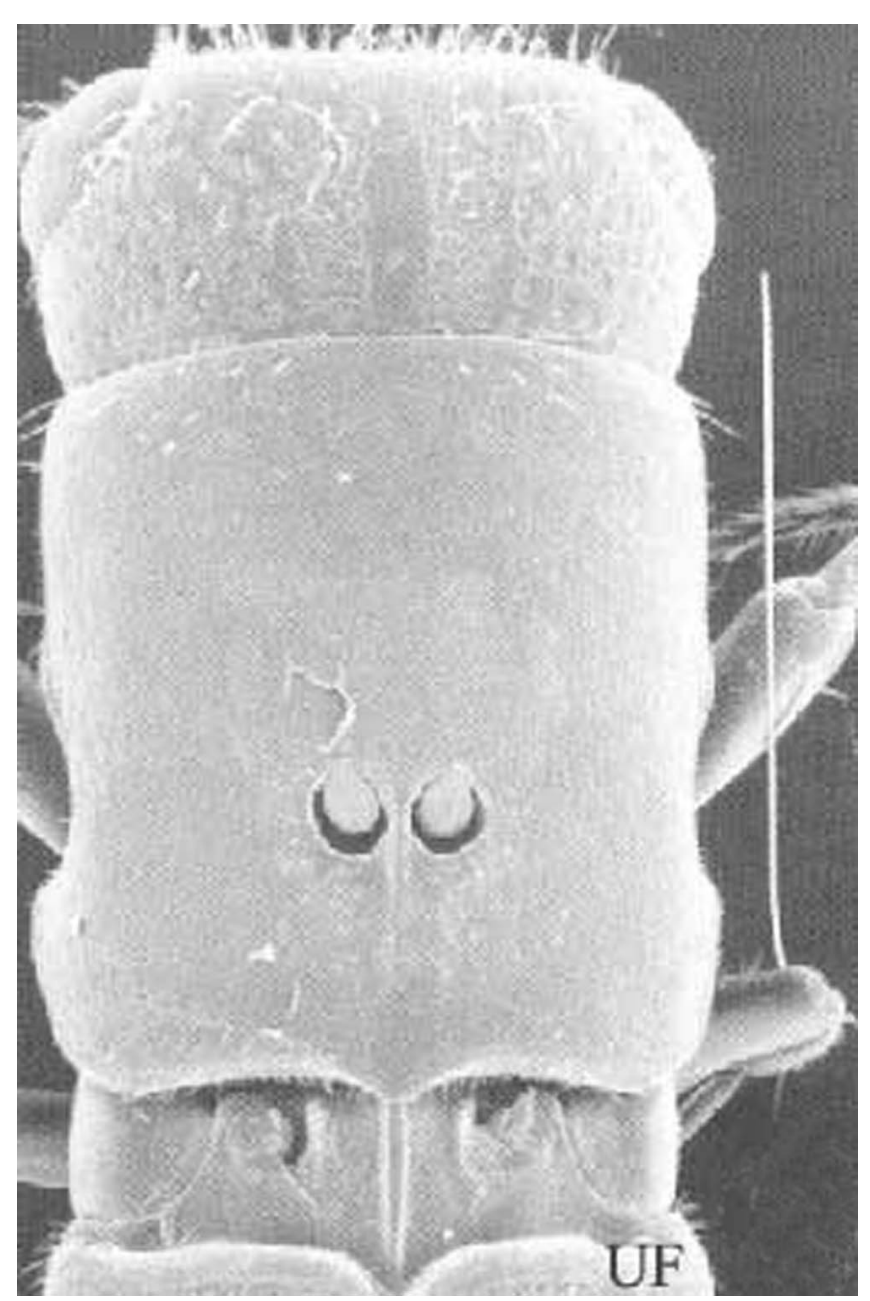

Figure 7. Pronotum of adult female Platypus quadridentatus (Olivier). White line represents $1 \mathrm{~mm}$. Credits: T.H. Atkinson, University of Florida

2' Male declivity without spines on venter of abdomen; posterolateral processes of declivity acute, not compressed (Figure 8); female declivity with blunt posterolateral projections on elytra, less acute than those of male (Figure 9); female pronotum without conspicuous pores. Southeastern U.S. In pines ..... flavicornis (Fabricius)

3(1). Pronotum of both sexes with a pair of tiny pores in middle (Figure 6); male elytral stride shallowly impressed, interstriae 3 times as wide as striae at base of declivity (Figure 10). Southeastern U.S. Neotropics ..... compositus (Say)

3' Pronotum without conspicuous pores in either sex; male elytral striae deeply impressed, subequal in width to interstriae at base of declivity (Figure 12). Southern Florida. Circumtropical ..... parallellus (Fabricius) 


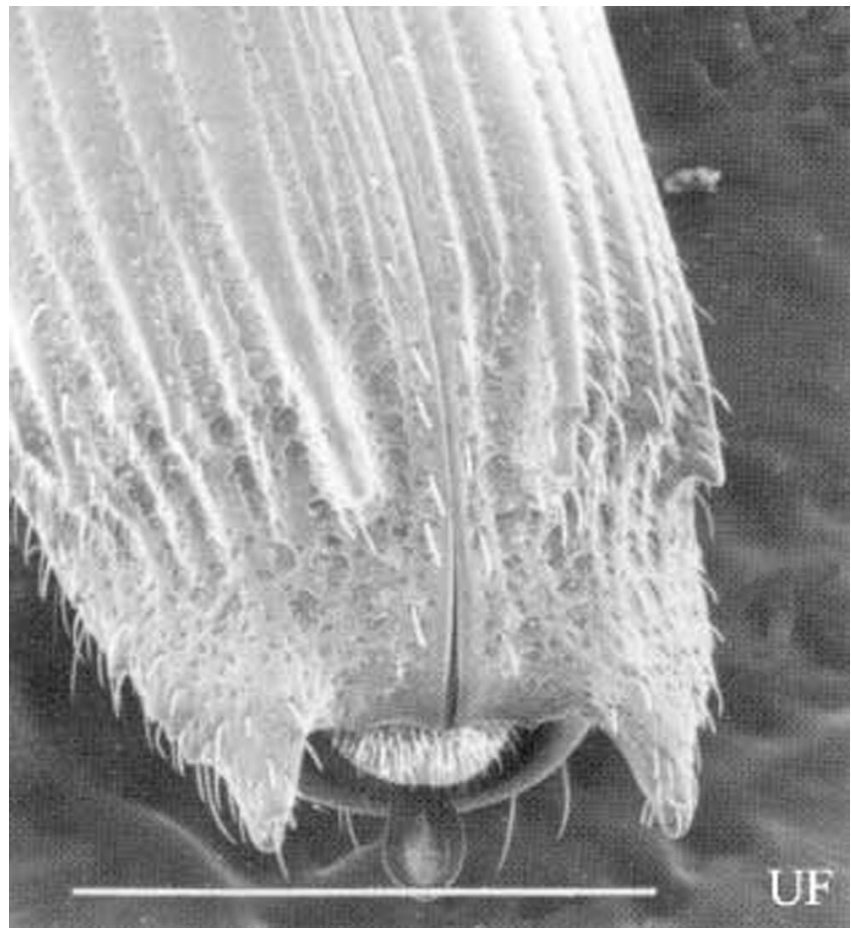

Figure 8. Male declivity in Platypus flavicornis (Fabricius). White line represents $1 \mathrm{~mm}$. Credits: T.H. Atkinson, University of Florida

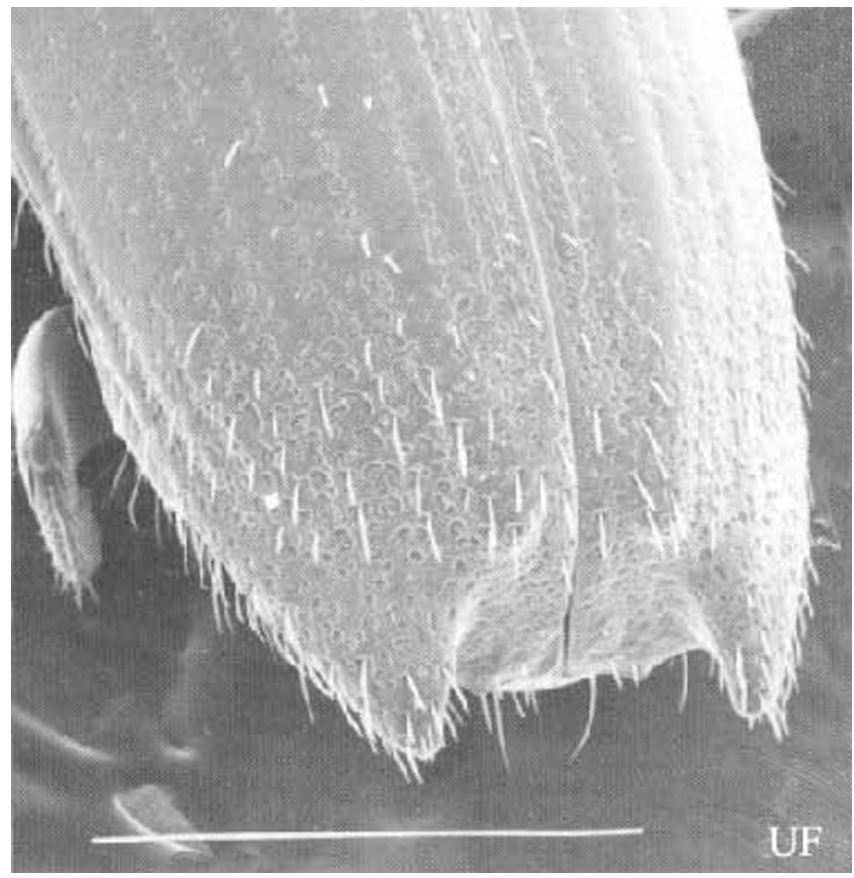

Figure 9. Female declivity in Platypus flavicornis (Fabricius). White line represents $1 \mathrm{~mm}$. Credits: T.H. Atkinson, University of Florida

\section{Biology}

All species are ambrosia beetles and generally breed in large diameter host material. Galleries are initiated by males; each male is joined by a single

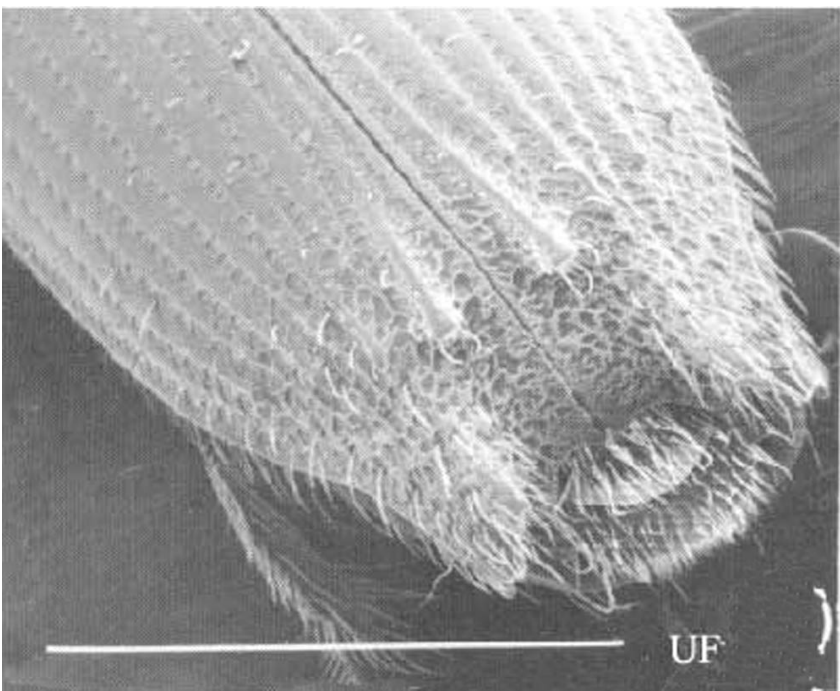

Figure 10. Male declivity in Platypus compositus (Say). White line represents $1 \mathrm{~mm}$. Credits: T.H. Atkinson, University of Florida

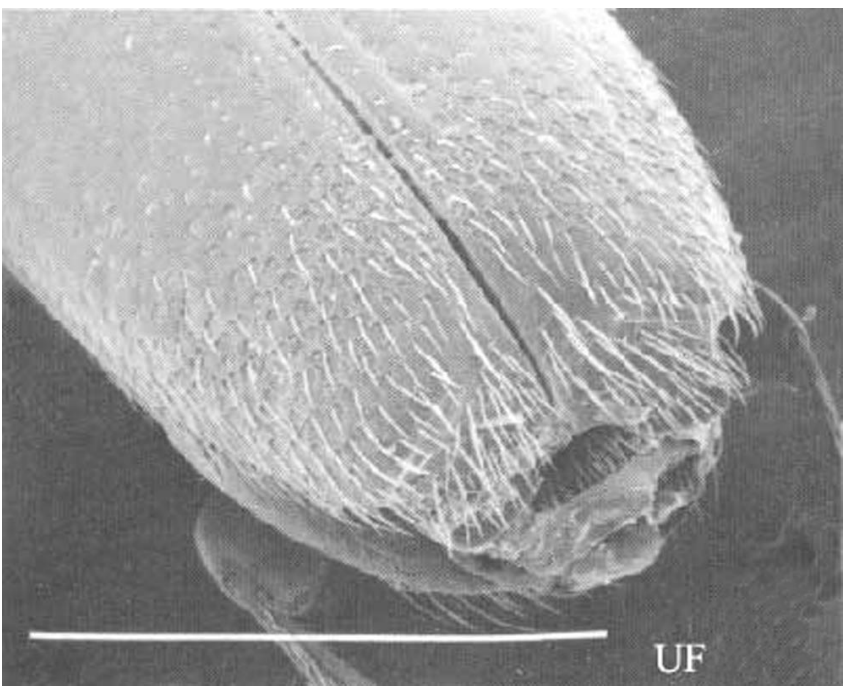

Figure 11. Female declivity in Platypus compositus (Say). White line represents $1 \mathrm{~mm}$. Credits: T.H. Atkinson, University of Florida

female. Apparently pheromones are produced and large numbers of simultaneous attacks are frequently observed. Mated pairs tunnel into the heartwood and introduce ectosymbiotic fungi into their tunnels upon which they and their brood feed. For the most part the wood is not actually consumed. Larvae move freely inside the parental tunnels and excavate individual pupal cells off the main tunnels. Adults emerge through the original entry hole. Platypodids can only breed in undegraded, recently killed host material, with a high moisture content. Decaying wood or wood which has dried out is unsuitable. Normally, only a single generation can be produced in a given 


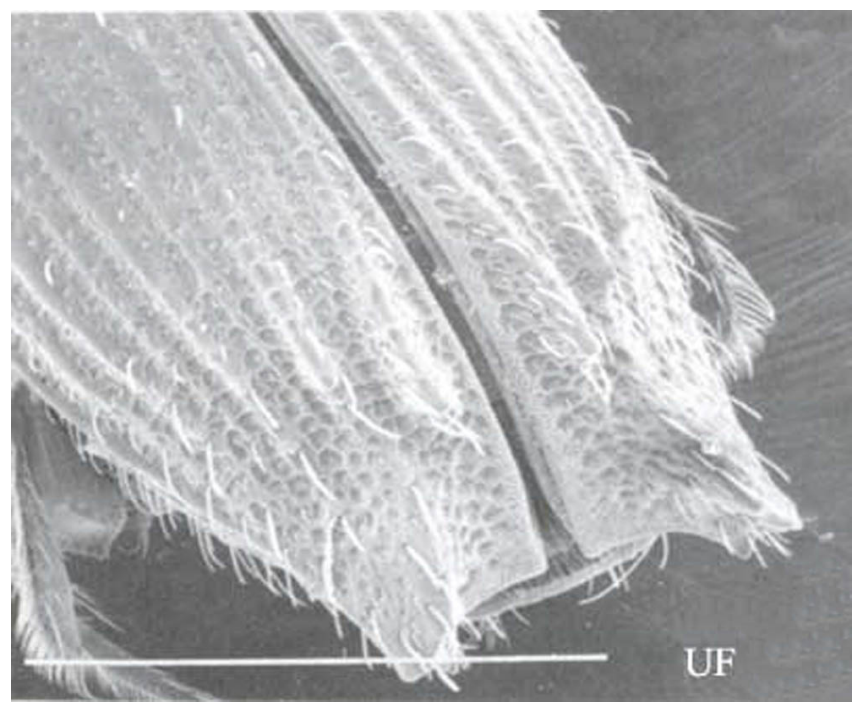

Figure 12. Male declivity in Platypus parallelus (Fabricius) .White line represents $1 \mathrm{~mm}$. Credits: T.H. Atkinson, University of Florida

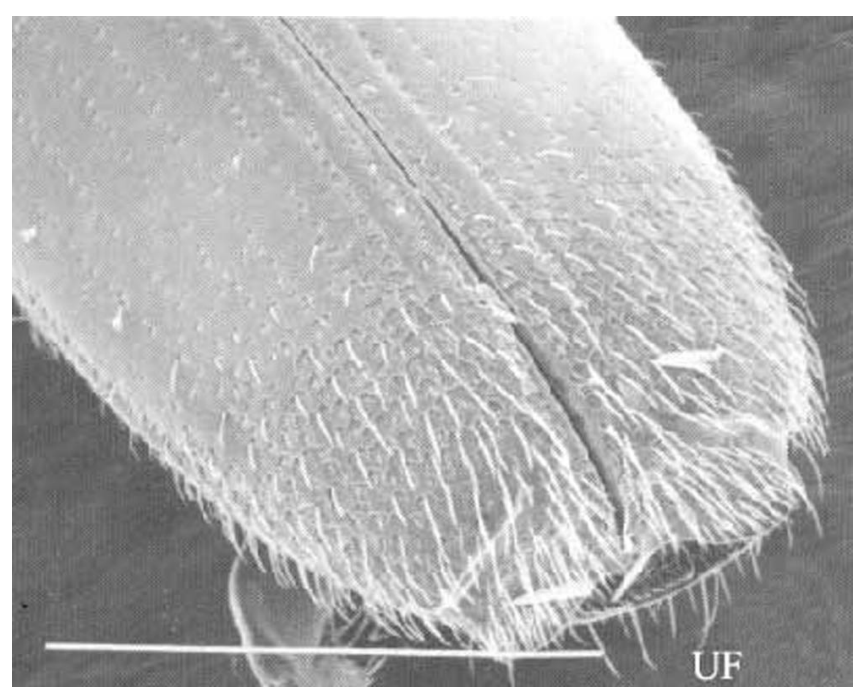

Figure 13. Female declivity in Platypus parallelus (Fabricius) . White line represents $1 \mathrm{~mm}$. Credits: T.H. Atkinson, University of Florida

host. Platypus flavicornis and P. quadridentatus are respectively restricted to pines and oaks. Platypus compositus and $P$. parallelus are extremely polyphagous and will breed in most trees within their ranges. These latter two species are commonly attracted to light.

\section{Distribution}

See Figures 16, 17, 18 and 19.

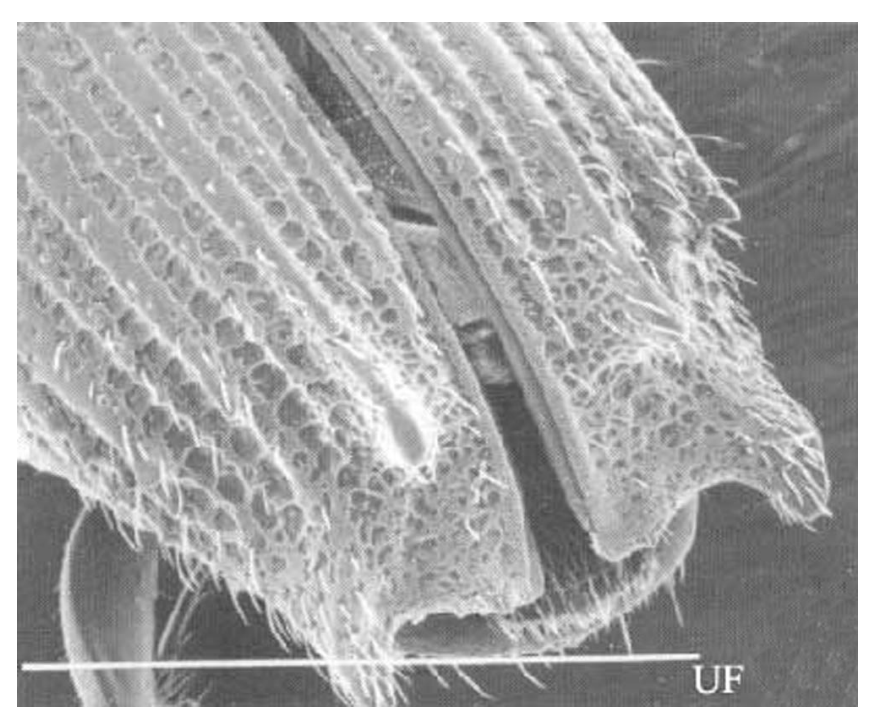

Figure 14. Male declivity in Platypus quadridentatus (Olivier) White line represents $1 \mathrm{~mm}$. Credits: T.H. Atkinson, University of Florida

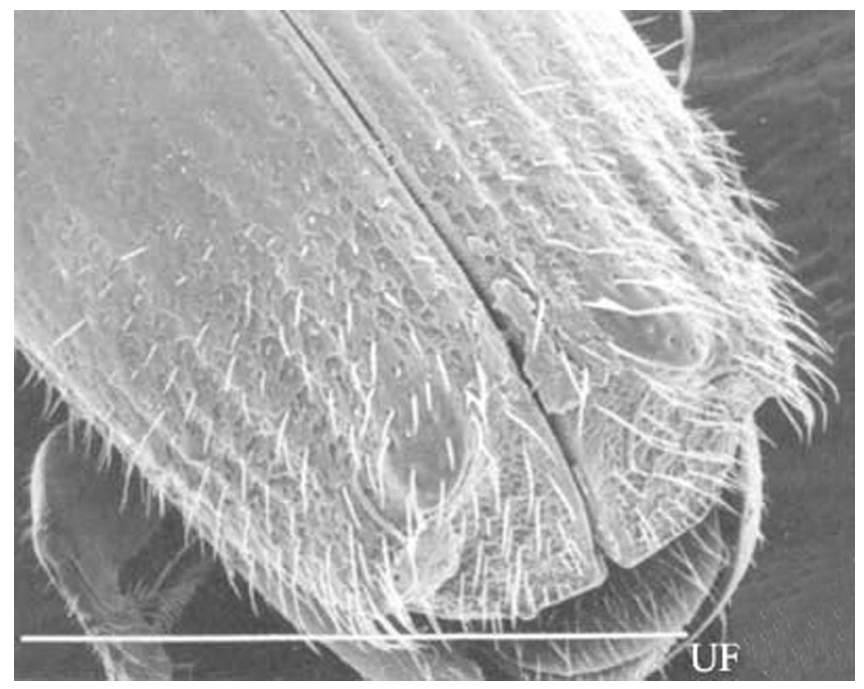

Figure 15. Female declivity in $P$. quadridentatus (Olivier). White line represents $1 \mathrm{~mm}$. Credits: T.H. Atkinson, University of Florida

\section{Damage}

\section{Selected References}

Beal, J.A., and C.L. Massey. 1945. Bark beetles and ambrosia beetles (Coleoptera: Scolytoidea) with special reference to the species occurring in North Carolina. Duke Univ. Sch. Forestry Bull. No. 10. 178 pp.

Blackman, M.W. 1922. Mississippi bark beetles. Miss. Agric. Exp. Sta. Tech. Bull. 11: 1- 130. 


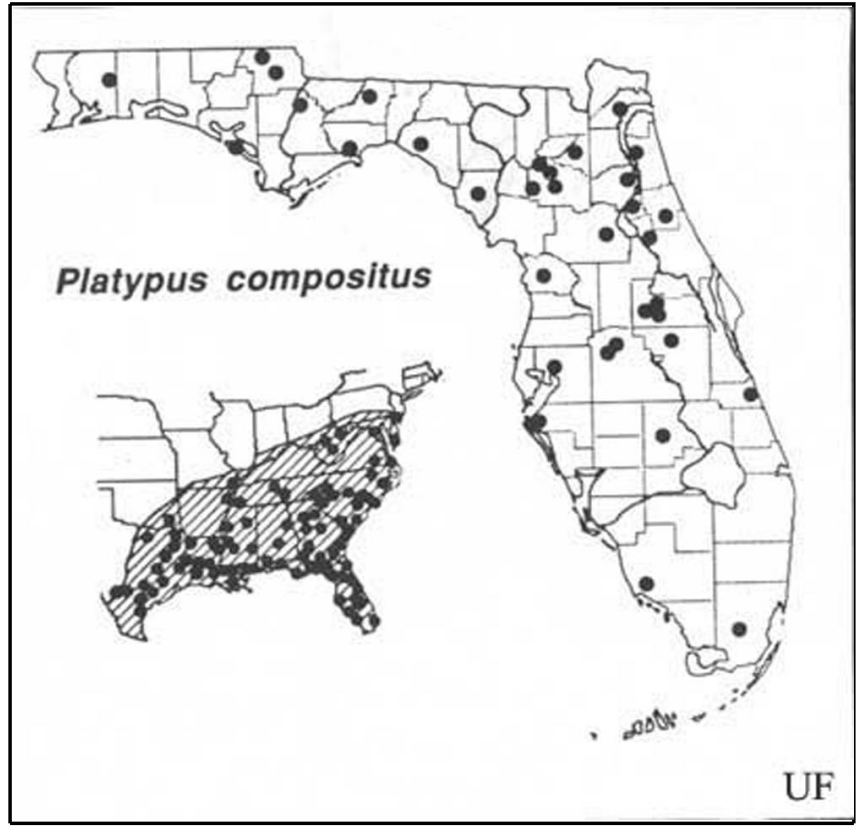

Figure 16. Distribution of Platypus compositus (Say). Based on Beal \& Massey (1945), Blackman (1922), Wood (1958, 1979), Staines (1981) and personal observations. Credits: T.H. Atkinson, University of Florida

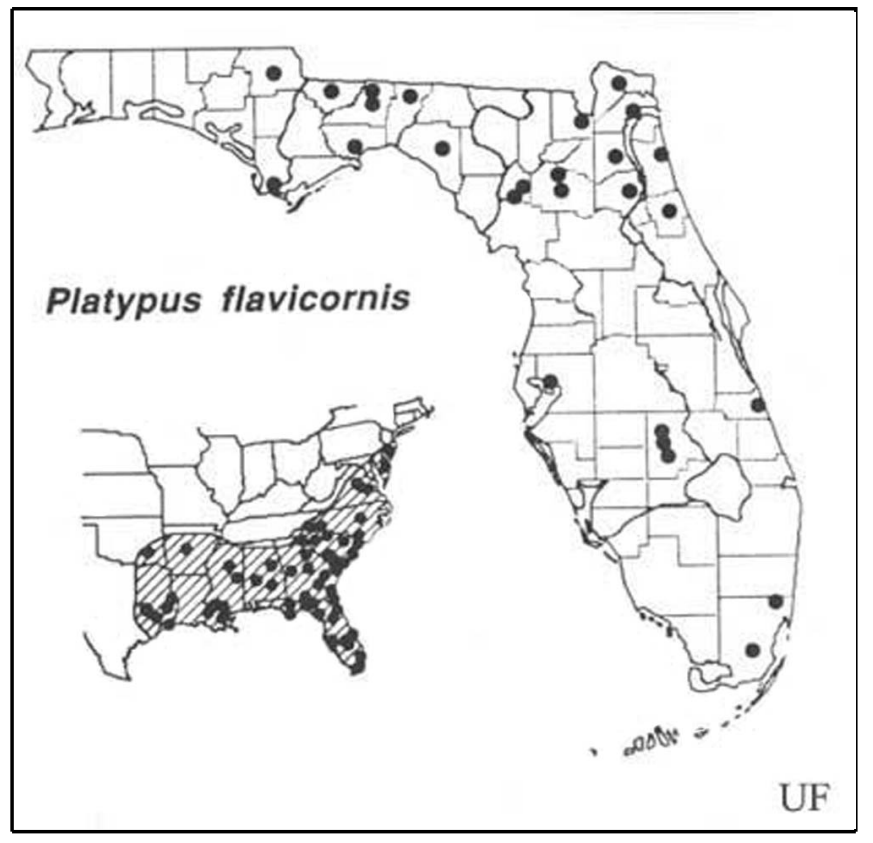

Figure 17. Distribution of Platypus flavicornis (Fabricius). Based on Beal \& Massey (1945), Blackman (1922), Wood (1958, 1979), Staines (1981) and personal observations. Credits: T.H. Atkinson, University of Florida

Chamberlin, W.J. 1939. The bark and timber beetles of North America north of Mexico. Oregon St. Univ., Corvallis. 513 p.

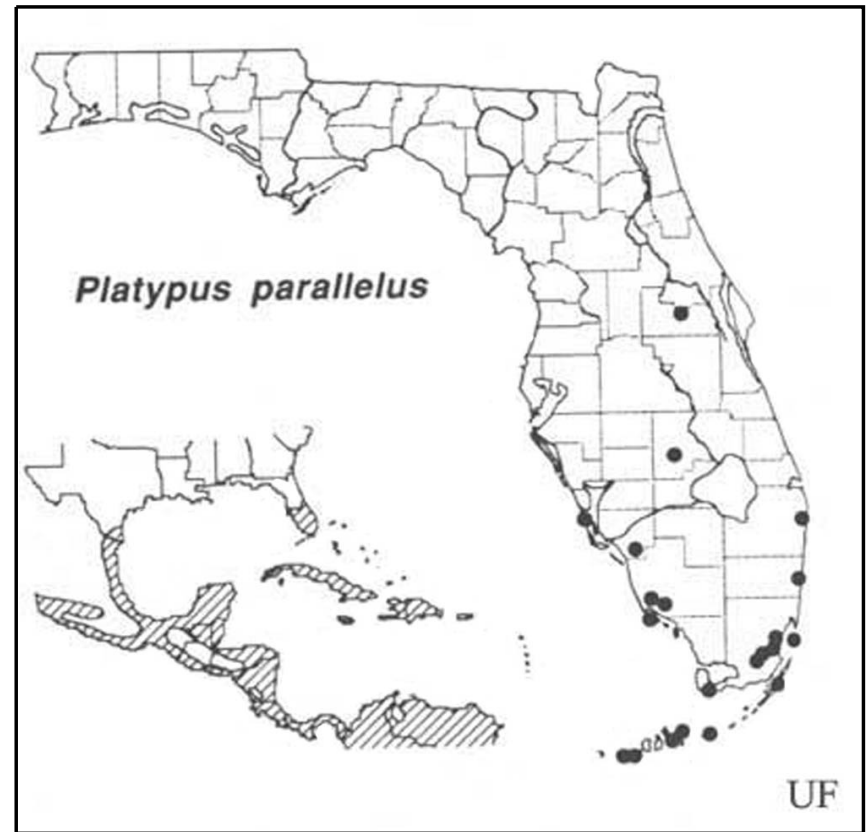

Figure 18. Distribution of Platypus parallelus (Fabricius). Based on Beal \& Massey (1945), Blackman (1922), Wood (1958, 1979), Staines (1981) and personal observations. Credits: T.H. Atkinson, University of Florida

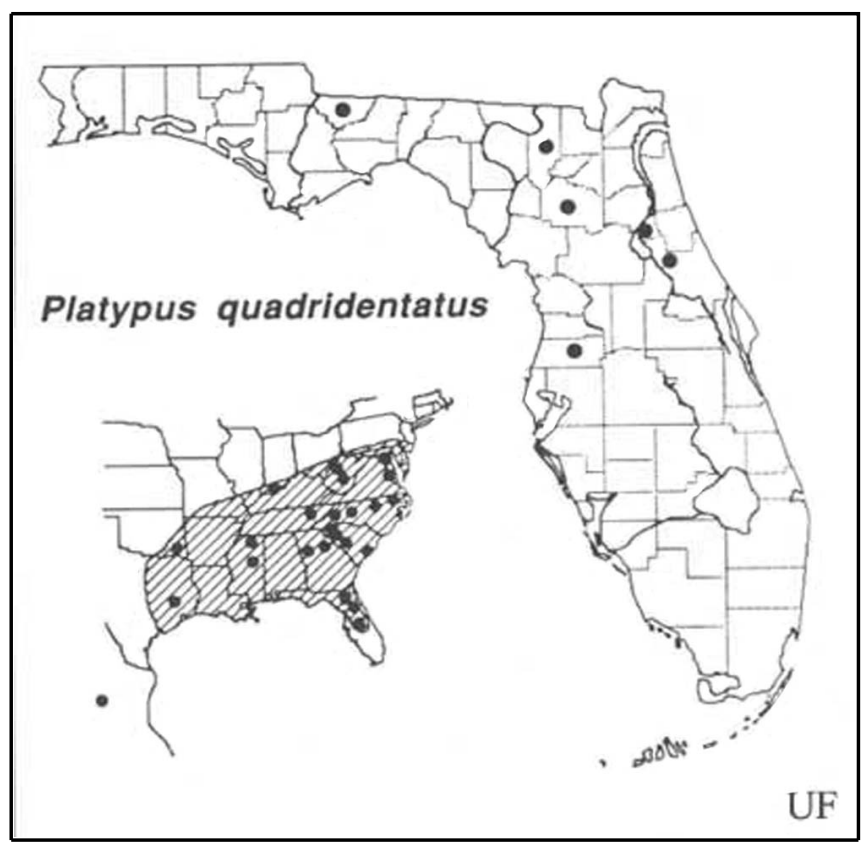

Figure 19. Distribtuion of Platypus quadridentatus (Olivier). Based on Beal \& Massey (1945), Blackman (1922), Wood (1958, 1979), Staines (1981) and personal observations. Credits: T.H. Atkinson, University of Florida

Schedl, K.E. 1972a. Monographie der Famile Platypodidae (Coleoptera). W. Junk, the Hague. 322 p. 


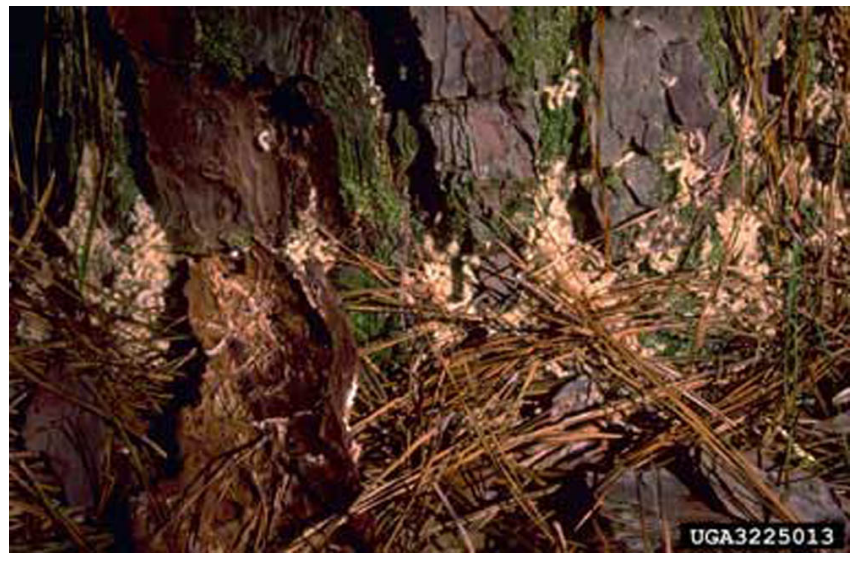

Figure 20. Boring dust at base of tree resulting from boring of the ambrosia beetle Platypus flavicornis Fabricius. Credits: Ronald F. Billings, Texas Forest Service, www.forestryimages.org

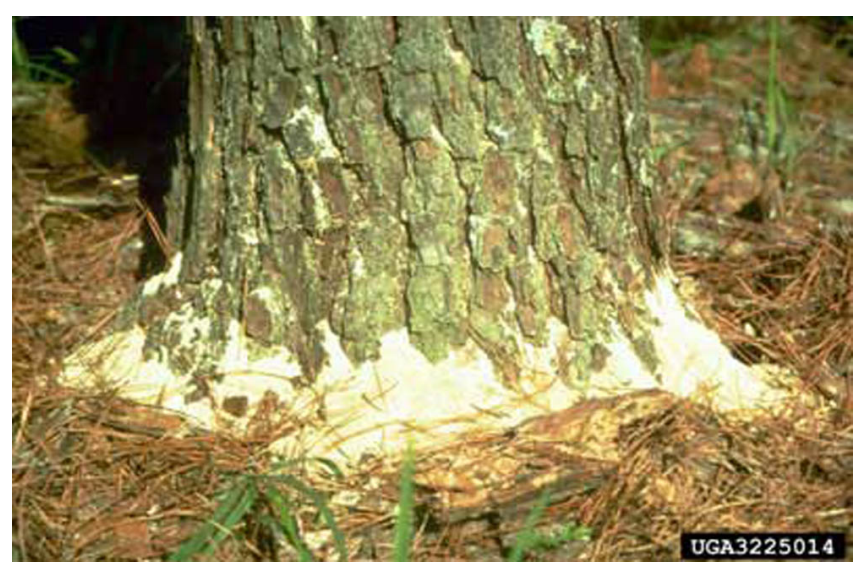

Figure 21. Boring dust (stage 3 ) at base of tree resulting from feeding of the ambrosia beetle Platypus flavicornis Fabricius. Credits: Ronald F. Billings, Texas Forest

Service, www.forestryimages.org

Staines, C.L. 1982. Distributional records of Platypodidae (Coleoptera) in Maryland. Proc. Ent. Soc. Wash. 84: 858-859.

Wood, S.L. 1958. Some virtually unknown North American Platypodidae (Coleoptera). Great Basin Natur. 18: 37-40.

Wood, S.L. 1979. Family Platypodidae. A Catalog of the Coleoptera of America north of Mexico, fasc. 141. U.S. Dept. Agric. Agric.

Handbook 529-141. 5 p. 